\section{PREPARATION OF GEOTHERMAL SILICA GLASS COATING FILM THROUGH MULTI-FACTOR OPTIMIZATION}

\section{S. Silviana ${ }^{a *}$, Gelbert Jethro Sanyotob, Adi Darmawanc}

aDepartment of Chemical Engineering, Faculty of Engineering, Diponegoro University, 50275, Tembalang, Semarang, Indonesia bMaster Program of Chemical Engineering, Faculty of Engineering, Diponegoro University, 50275, Tembalang, Semarang, Indonesia 'Department of Chemistry, Faculty of Engineering, Diponegoro University, 50275, Tembalang, Semarang, Indonesia
Article history

Received

7 December 2020

Received in revised form

4 April 2021

Accepted

27 April 2021

Published online

20 June 2021

${ }^{*}$ Corresponding author silviana@che.undip.ac.id

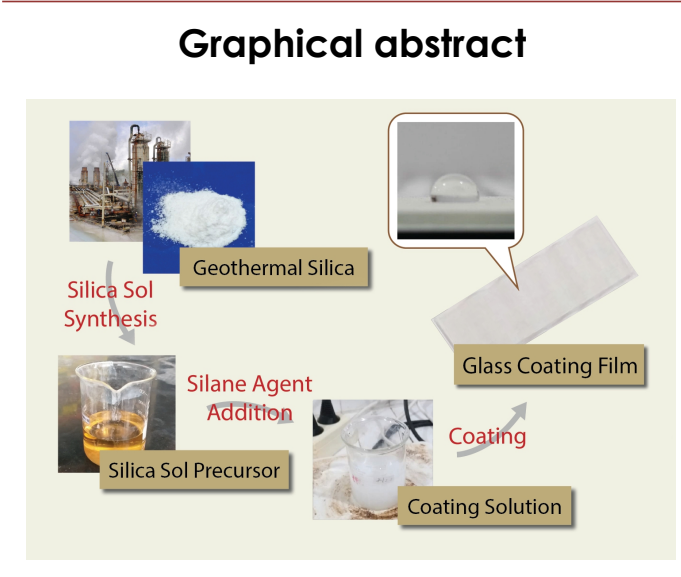

\begin{abstract}
Glass coating films have been developed by many researchers in recent years. However, mass commercialization of this technology is still inefficient. An appropriate method is required to generate affordable product. This paper observes a film preparation method using silica glass of geothermal waste silica derived from geothermal power plants. Geothermal waste has been used as silica precursor and modified using several silylation agents such as methyltriethoxysilane (MTMS), hexamethyldisilazane (HMDS), polydimethylsiloxane (PDMS), and surface-active agent (surfactant) cethyltrimethylammoniumbromide (CTAB). Design Expert 8.0.6 is used for optimization to find the desired product at the concentration of specific precursors and silane agents using contact angle responses. A model consisting statistically significant variables can be generalized to abroad data range. The results of this study indicate that the glass surface coated with modified silica produces hydrophobic glass with contact angles up to $90^{\circ}$ using the MTMS silylation agent.
\end{abstract}

Keywords: Geothermal silica, glass coating, hydrophobic glass, multi-factor optimization

(C) 2021 Penerbit UTM Press. All rights reserved

\subsection{INTRODUCTION}

The "lotus leaf effect" has attracted the attention of many researchers around the world to develop selfcleaning glass technology. In addition to a variety of applications, this technology is useful in reducing maintenance costs by eliminating tedious manual cleaning work [1]. This potential has encouraged efforts to replicate the lotus leaf effect. The surface design of a lotus leaf consists of a micro/nano hierarchical structure, that creates low free-surface energy, thereby preventing water from wetting the surface of the leaf [2]. To produce self-cleaning properties on glass surfaces, previous studies have attempted to modify the glass surface by using nanoparticles such as $\mathrm{ZnO}, \mathrm{SiO} 2, \mathrm{TiO} 2$ [3-5] and carbon or polymer particles [6, 7].

As one of the most abundant minerals from the earth's crust, $\mathrm{SiO} 2$ has the highest potential to be produced as a glass coating. However, silica is present as mined mineral sand, and it can be formed naturally in rice husk [8], bamboo leaf [9, 10], 
bagasse ash [11, 12], rice husk [13], and coal ash [14]. In various geothermal power plants, silica can also be applied as scale in piping equipment [15]. For example, silica can be released from the geothermal power plant in Dieng generating a huge amount of solid waste. This condition has been a problem because waste accumulation in the form of saltwater solution has reached 10 tons/day and generates approximately $10 \%$ of solid silica scale waste [16]. However, many observations of the geothermal silica have been conducted in several researches [17-20].

Surface modification of silica nanoparticles originates from the behavior of hydroxyl groups on the surface of silica. These hydroxyl groups can be substituted by other functional groups. The product can have completely different behavior such as surface hydrophobicity. The hydroxyl group can be substituted into other groups, such as trimethylsilyl producing hydrophobic materials [21]. This modification can be achieved by using silica precursors reacted with several silylating agents, including trimethylchlorosilane (TMCS) [22-24], hexamethyldisilazane (HMDS) [25, 27], methyltrimethoxysilane (MTMS) [27, 28], or polydimethylsiloxane (PMDS) [21, 29].

However, optimization and multifactorial testing should be conducted to limit the usage of silane agents and the possibility of interaction between many variables. Limiting the use of materials, especially the silane agents, can minimize the product cost and increase the potential for commercialization. Therefore, in this study, a multifactor optimization is applied to prepare glass coating film using a precursor derived from geothermal power plant silica. Design Expert 8.0.6 software is used in the design process. This study revealed that the contact angle of distilled water on the coated glass with a higher contact angle can be achieved.

\subsection{METHODOLOGY}

\subsection{Preparation of Silica Precursor}

\section{Geothermal Silica Pre-treatment}

Silica from geothermal power plant was treated by drying with the temperature of $105^{\circ} \mathrm{C}$, followed by size reduction through high-energy milling for $10 \mathrm{~min}$ and screened using Vibratory Sieve Shaker of the series AS 200, 325 mesh (45 micrometer). The procedure had used previous research with slight modification such as ratio of silica over sulfuric acid $[17,30]$. The geothermal silica was mixed with sulfuric acid through leaching process at temperature of $100^{\circ} \mathrm{C}$. The leaching process allowed for $1 \mathrm{~h} 45 \mathrm{~min}$. Pretreated silica soaked in acidic solution sulfuric acid at 1:5 (w/V) was prepared at temperature of $100^{\circ} \mathrm{C}$ with constant stirring. After the slurry was formed, the solution mixture was screened through filter paper, and it was neutralized by washing and then dried using oven at $105^{\circ} \mathrm{C}$ until a constant weight was obtained. Therefore, $2 \mathrm{~N} \mathrm{NaOH}$ solution was added to the silica solids obtained with a ratio of silica over sodium hydroxide about 1:6 (w/v) and stirred until all silica was dissolved to generate a solution of $\mathrm{Na}_{2} \mathrm{SiO}_{3}$. Then, hydrochloric acid $(\mathrm{HCl}) 1 \mathrm{~N}$ was dropped to $\mathrm{Na}_{2} \mathrm{SiO}_{3}$ solution gradually until colloidal condition at acidic conditions and left by aging for 18 hours. Finally, demineralized water was used to wash the silica gel to remove residual salt and impurity. After that silica gel was introduced ambient pressure drying at $105^{\circ} \mathrm{C}$.

\section{Synthesis of Silica Precursor}

In this study, the silica precursor used was water glass (sodium silicate) obtained through sol-gel method using $\mathrm{NaOH}$ and $\mathrm{HCl}$. These steps were conducted to eliminate the impurity of geothermal silica. The $\mathrm{NaOH}$ used in the sol process was $6 \mathrm{~N}$ with silica to $\mathrm{NaOH}$ solution ratio being 1:6 (w/V). After filtration, the filtrate as water glass solution was administered with $\mathrm{HCl} 1 \mathrm{~N}$ at various ratios $(1: 5,1: 8,1: 10 \mathrm{v} / \mathrm{v})$ to form a gel at room temperature. Then, the solution was aged for $18 \mathrm{~h}$ to yield silica gel. Distilled water was used to wash silica gel, and then silica gel was dried at $105^{\circ} \mathrm{C}$. Dry silica was synthesized to produce a water glass precursor or sodium silicate.

\subsection{Glass Coating Preparation}

\section{Experimental Design}

Experiment design and optimization were conducted using statistical method with Design Expert 8.0.6 by applying a regular two-level factorial design to estimate main effects and interactions. The experiment two factors with 12 runs. Sodium silicate and silane agent concentration as the numeric factors were conducted with a low level of $2 \%$ and a high level of $8 \%$, while silane agent type as categorical factors were MTMS, HMDS, and PMDS. Initially, the sodium silicate was dissolved in water, and the surfactant of cetylmethylammonium bromide (CTAB) was dissolved in ethanol. The response would be recorded as a contact angle in six measurements.

Sodium silicate and silane agent solutions at the predetermined concentrations were adjusted to $\mathrm{pH}$ $=2.0$ using $\mathrm{HCl} 1 \mathrm{~N}$ to obtain a sol solution, while the gel formation was approximately up to $\mathrm{pH}$ 5.0. The sol solution was then mixed with ratio 1:1 (V/V) and added with 0.1 gram of CTAB under constant stirring for 1 hour. The sol solution was adjusted to reach $\mathrm{pH}=$ 5.0 using $\mathrm{NaOH} 1 \mathrm{~N}$ to form gel. The original randomized runs are presented in Table 1. Design Expert software automatically lists the runs in randomized order, protecting against any lurking factors through the standard order (Std) function. 
Table 1 Randomized $2^{2}$ factorial experiment design generated from Expert 8.0.6. The same process is applied for each silane agent type

\begin{tabular}{ccc}
\hline Run & $\begin{array}{c}\text { Factor 1 A : } \\
\text { Sodium silicate (\%) }\end{array}$ & $\begin{array}{c}\text { Factor 2 B : } \\
\text { Silane agent (\%) }\end{array}$ \\
\hline 1 & 8 & 2 \\
2 & 2 & 2 \\
3 & 2 & 2 \\
4 & 8 & 8 \\
5 & 8 & 2 \\
6 & 2 & 8 \\
7 & 8 & 2 \\
8 & 2 & 2 \\
9 & 2 & 8 \\
10 & 8 & 8 \\
11 & 2 & 8 \\
12 & 8 & 8 \\
\hline
\end{tabular}

\section{Coating Application}

The mixed solution was applied to an alcoholwashed glass substrate by spray method. The coated glass was dried by ambient air and its contact angle was analyzed.

\section{3 Characterization}

All response data of coated glasses was analyzed contact angle using Race Contact angle. The other characterization have been conducted by doing analysis of BET-BJH (Autosorb IQ of Quantachrome Instrument, Austria), FTIR (IRPrestige2l of Shimadzu, Japan), SEM EDX (Thermo Fischer Scientific, USA), and AFM (Park System XE-70, USA) to confirm the results.

\subsection{RESULTS AND DISCUSSION}

\subsection{Preparation of Silica Precursor}

Initially, silica from geothermal solid waste was treated by acid leaching using sulfuric acid. Table 2 shows the conditions before and after acid leaching based on composition analysis using XRF.

Through acid leaching, the treated silica consisted of reduced components due to cut of ionic bonds of metal impurities with $\mathrm{O}_{2}$ from the interaction between $\mathrm{H}_{2} \mathrm{SO}_{4}$ and metal oxides. Furthermore, binding of $\mathrm{SO}_{4}{ }^{2-}$ ions with metal elements released metal sulfate compounds while binding of $\mathrm{H}^{+}$ions with oxygen released $\mathrm{H}_{2} \mathrm{O}$. Meanwhile, high-concentration $\mathrm{H}_{2} \mathrm{SO}_{4}$ can inhibit itself by in-situ deposition on metal surface [31].
Table 2 Composition analysis using XRF for raw silica (prior) and leached silica (prior) by sulfuric acid

\begin{tabular}{lcc}
\hline Component & Before (\%) & After (\%) \\
\hline Silica & 86.30 & 98.20 \\
Potassium & 5.67 & - \\
Calcium & 3.21 & 0.95 \\
Chromium & 0.07 & 0.07 \\
Manganese & 0.09 & 0.07 \\
Iron & 3.59 & 0.53 \\
Nickel & 0.03 & 0.02 \\
Cuprum & 0.10 & 0.07 \\
Zinc & 0.08 & - \\
Arsenic & 0.32 & - \\
Bromine & 0.19 & - \\
Rubidium & 0.09 & - \\
Ytterbium & 0.07 & 0.08 \\
Rhenium & 0.08 & - \\
Plumbum & 0.10 & - \\
\hline
\end{tabular}

\subsection{Effect on Acid Ratio in Gelation}

Preparation of the glass coating film was closely related to the surface modification step. In this study, surface modification aims to replace the hydrophilic hydroxyl group of silica with a hydrophobic trimethylsilyl group. Figure 1 shows an example of reaction following the surface modification.

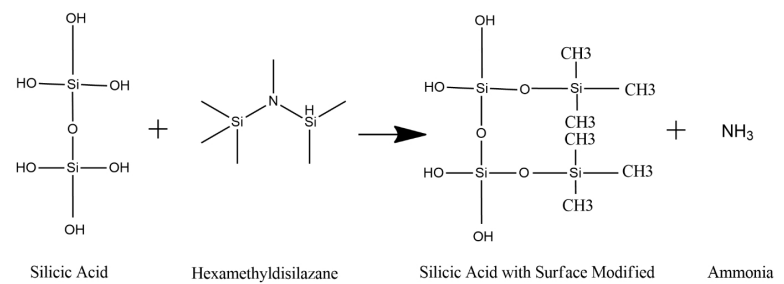

Figure 1 Surface modification using HMDS [32]

Although the surface of silica itself contains many hydroxyl groups, surface modification depends on the surface area of a specific material. Therefore, higher surface area is preferable to maximize the substitution of hydroxyl groups. A previous study stated that the silica surface area was related to the ratio of silica sol to acid volume in the gelation step of the sol-gel method [33]. Thus, the $\mathrm{HCl}$ volume varies to 1:5, 1:8, and 1:10 (v/v). Figure 2 shows the result of Brunauer-Emmett-Teller (BET) analysis. BET analysis is used to calculate the surface area and pore distribution of the geothermal silica [34]. 

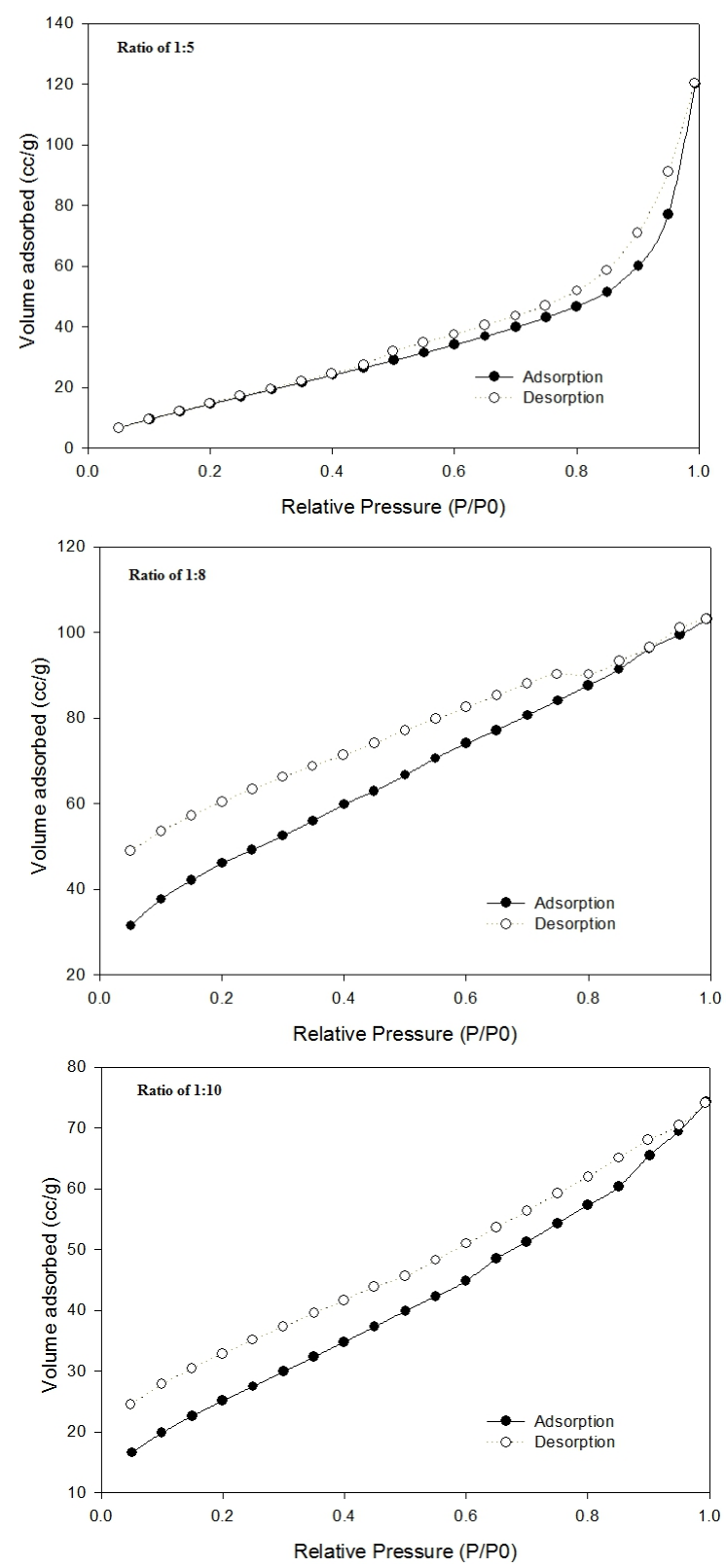

Figure 2 Sorption isoterm curve for silica particles obtained from gelation using silica sol-to-HCl ratio

Overall surface area, pore volume, and pore radius data are summarized in Table 3.

Table 3 BET analysis of geothermal silica

\begin{tabular}{lllcc}
\hline Parameter & Raw & HCl 1:5 & HCl 1:8 & HCl 1:10 \\
\hline $\begin{array}{l}\text { Surface area } \\
\left(\mathrm{m}^{2} / \mathrm{g}\right)\end{array}$ & 40.90 & 73.53 & 165.4 & 96.99 \\
$\begin{array}{l}\text { Pore volume } \\
(\mathrm{cc} / \mathrm{g})\end{array}$ & 0.13 & 0.179 & 0.097 & 0.084 \\
$\begin{array}{l}\text { Pore radius } \\
(\AA)\end{array}$ & 19.83 & 15.30 & 19.11 & 17.05 \\
\hline
\end{tabular}

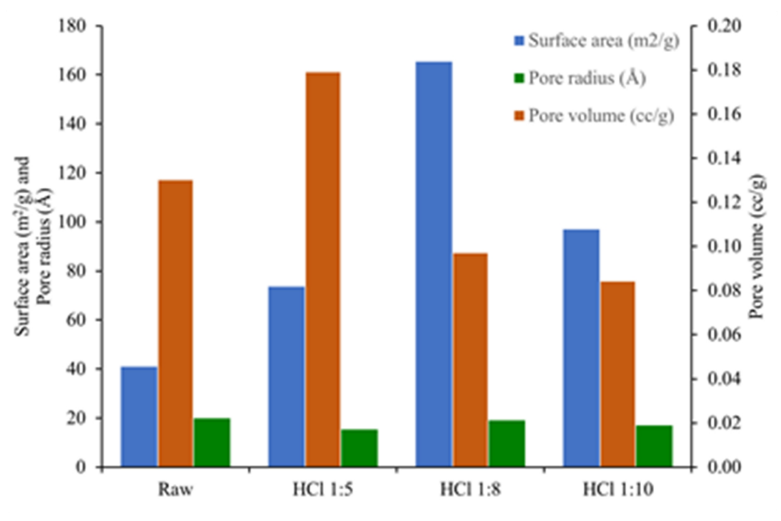

Figure 3 Surface area, pore volume, and pore radius of geothermal silica and silica aerogel

As shown in Table 3 and Figure 3, the sol-gel method may increase the silica surface area. This finding is similar to that of other studies [35]. Nevertheless, the ratio of silica sol-to- $\mathrm{HCl}$ also relates to the surface area in which the addition of $\mathrm{HCl}$ at 1:8 (v/v) results in the highest surface area compared with 1:5 and 1:10. A possible explanation of this result is the property of silica gel itself, which is influenced by solution $\mathrm{pH}$. Silica is soluble in basic solution as natrium silicate sol. By adjusting the $\mathrm{pH}$ to neutral, silica sol may transform into a condensed structure known as silica gel [36]. Failure to reach this neutral $\mathrm{pH}$ (lower $\mathrm{HCl}$ addition) may hamper the gelation. However, by adding more $\mathrm{HCl}(1: 10)$, lower $\mathrm{pH}$ makes the solution acidic, which may hinder the silica condensation rate [37], thereby creating less surface area. The mean radius is $17.8 \AA$, with a low deviation $( \pm 1.78 \AA)$, which indicates that the variation of additional $\mathrm{HCl}$ does not have a significant effect on the pore radius. Pore volume values for the three samples are shallow and indicate that only a small portion of this material is porous. Most of this material is porous and non-dense. This characteristic is good because the resulting silica thin layer produces a dense surface and tends to be non-porous.

\subsection{Glass Coating Statistical Optimization}

Table 4 presents the contact angle measurement of 36 coated glass samples. 
Table 4 Contact angle measurement results of coated glass

\begin{tabular}{|c|c|c|c|c|}
\hline Run & $\begin{array}{l}\text { Category: } \\
\text { Silane } \\
\text { agent type }\end{array}$ & $\begin{array}{l}\text { Factor } 1 \\
\text { A: } \\
\text { Sodium } \\
\text { silicate } \\
\text { (\%) }\end{array}$ & $\begin{array}{l}\text { Factor } 2 \\
\text { B: Silane } \\
\text { agent } \\
(\%)\end{array}$ & $\begin{array}{l}\text { Response: } \\
\text { Contact } \\
\text { angle }\left({ }^{\circ}\right)\end{array}$ \\
\hline 1 & \multirow{12}{*}{ MTMS } & 2 & 2 & $134.5 \pm 2.3$ \\
\hline 2 & & 2 & 2 & $132.9 \pm 1.3$ \\
\hline 3 & & 2 & 2 & $125.7 \pm 2.9$ \\
\hline 4 & & 8 & 2 & $98.5 \pm 5.1$ \\
\hline 5 & & 8 & 2 & $105.3 \pm 6.1$ \\
\hline 6 & & 8 & 2 & $109.7 \pm 4.7$ \\
\hline 7 & & 2 & 8 & $90.7 \pm 0.9$ \\
\hline 8 & & 2 & 8 & $89.7 \pm 0.7$ \\
\hline 9 & & 2 & 8 & $86.4 \pm 2.6$ \\
\hline 10 & & 8 & 8 & $79.3 \pm 2.3$ \\
\hline 11 & & 8 & 8 & $93.8 \pm 1.8$ \\
\hline 12 & & 8 & 8 & $91.4 \pm 4.2$ \\
\hline 1 & \multirow{12}{*}{ HMDS } & 2 & 2 & $72.3 \pm 5.1$ \\
\hline 2 & & 2 & 2 & $74.4 \pm 3.8$ \\
\hline 3 & & 2 & 2 & $93.0 \pm 5.4$ \\
\hline 4 & & 8 & 2 & $86.5 \pm 3.3$ \\
\hline 5 & & 8 & 2 & $93.1 \pm 2.8$ \\
\hline 6 & & 8 & 2 & $105.1 \pm 1.3$ \\
\hline 7 & & 2 & 8 & $49.6 \pm 4.0$ \\
\hline 8 & & 2 & 8 & $69.1 \pm 3.3$ \\
\hline 9 & & 2 & 8 & $38.3 \pm 1.7$ \\
\hline 10 & & 8 & 8 & $31.1 \pm 1.4$ \\
\hline 11 & & 8 & 8 & $40.9 \pm 2.1$ \\
\hline 12 & & 8 & 8 & $36.8 \pm 2.7$ \\
\hline 1 & \multirow{12}{*}{ PDMS } & 2 & 2 & $75.8 \pm 4.5$ \\
\hline 2 & & 2 & 2 & $106.1 \pm 1.9$ \\
\hline 3 & & 2 & 2 & $108.3 \pm 5.8$ \\
\hline 4 & & 8 & 2 & $53.8 \pm 5.8$ \\
\hline 5 & & 8 & 2 & $45.6 \pm 4.6$ \\
\hline 6 & & 8 & 2 & $35.2 \pm 3.7$ \\
\hline 7 & & 2 & 8 & $78.1 \pm 0.5$ \\
\hline 8 & & 2 & 8 & $57.5 \pm 2.5$ \\
\hline 9 & & 2 & 8 & $106.9 \pm 2.7$ \\
\hline 10 & & 8 & 8 & $40.5 \pm 4.6$ \\
\hline 11 & & 8 & 8 & $52.9 \pm 3.5$ \\
\hline 12 & & 8 & 8 & $32.9 \pm 2.0$ \\
\hline
\end{tabular}

Based on Table 4, half-normal plots of data can be derived for each type of silane agent, i.e., Figure 4 for MTMS, HMDS, and PDMS, respectively.
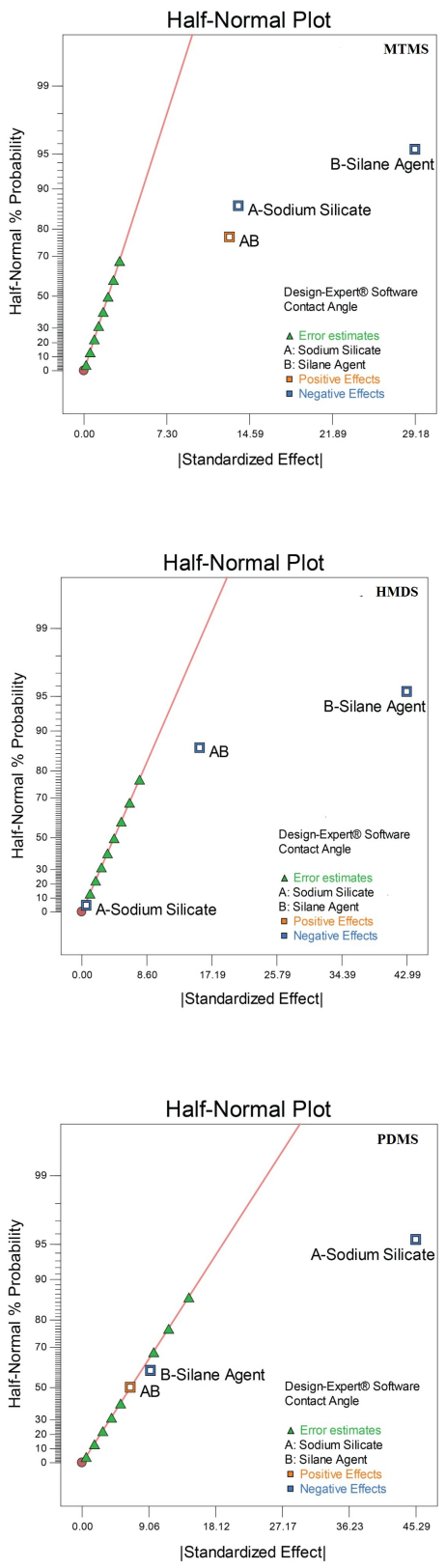

Figure 4 Half-normal plot of silica glass coating with contact angle response

Figure 4, where factor $A$ is sodium silicate, and factor $B$ is a silane agent from a half-normal plot, shows that the concentration of sodium silicate and silane agent has a negative effect on the response. However, factors $A$ and $B(A B)$ show positive effects that indicate the possible interaction between the two variables for MTMS and PDMS. This $A B$ interaction shows a negative effect on HMDS. Further studies of these interactions are analyzed using ANOVA to determine the significance of the model and are presented in Table 5. 
Table 5 ANOVA for silane type of factorial model ( $i=$ MTMS, $\mathrm{ii}=$ HMDS, iii $=$ PDMS) with all significant models

\begin{tabular}{|c|c|c|c|c|c|c|c|}
\hline \multirow[t]{2}{*}{ Source } & \multicolumn{3}{|c|}{ F-value } & \multicolumn{3}{|c|}{ Prob>F } & \multirow{2}{*}{$\begin{array}{l}\text { Signi } \\
\text { fican } \\
\text { cy }\end{array}$} \\
\hline & i & ii & iii & $\mathbf{i}$ & ii & iii & \\
\hline$\overline{\text { Model }}$ & 40.6 & 17.4 & 7.7 & $<10^{-4}$ & $<7.10^{-4}$ & $<9.10^{-4}$ & Signi- \\
\hline $\mathrm{A}-\mathrm{Na}-\mathrm{Si}$ & 18.8 & 0.01 & 21.7 & $2.5 .10^{-3}$ & 0.92 & $1.6 .10^{-3}$ & fica \\
\hline B-Silane & 86.2 & 46.2 & 0.9 & $<10^{-4}$ & $10^{-4}$ & $10^{-4}$ & \\
\hline$A B$ & 16.7 & 6.1 & 0.5 & $3.5 .10^{-3}$ & $\begin{array}{l}3.8 .10^{-} \\
2\end{array}$ & $3.8 .10^{-2}$ & \\
\hline$R^{2}$ & $\begin{array}{l}0.93 \\
83\end{array}$ & $\begin{array}{l}0.86 \\
74\end{array}$ & $\begin{array}{l}0.74 \\
26\end{array}$ & & & & \\
\hline $\begin{array}{l}\text { Adj R- } \\
\text { Squar } \\
\text { ed }\end{array}$ & $\begin{array}{l}0.91 \\
52\end{array}$ & $\begin{array}{l}0.81 \\
76\end{array}$ & $\begin{array}{l}0.64 \\
61\end{array}$ & & & & \\
\hline $\begin{array}{l}\text { Pred R- } \\
\text { Squar } \\
\text { ed }\end{array}$ & $\begin{array}{l}0.86 \\
12\end{array}$ & $\begin{array}{l}0.70 \\
16\end{array}$ & $\begin{array}{l}0.42 \\
08\end{array}$ & & & & \\
\hline $\begin{array}{l}\text { Adeq. } \\
\text { Precisi } \\
\text { on }\end{array}$ & $\begin{array}{l}13.6 \\
199\end{array}$ & $\begin{array}{l}9.26 \\
79\end{array}$ & $\begin{array}{l}5.61 \\
70\end{array}$ & & & & \\
\hline
\end{tabular}

The ANOVA of the factorial model shows that the $p$-value of all the models is below 0.05. Thus, the model is considered statistically significant. Consequently, the interaction patterns of these findings tend to generalize a broader data range. The interaction between variables (sodium silicate and silane agent concentration) and resulting response (contact angle) can be observed in Figure 5.

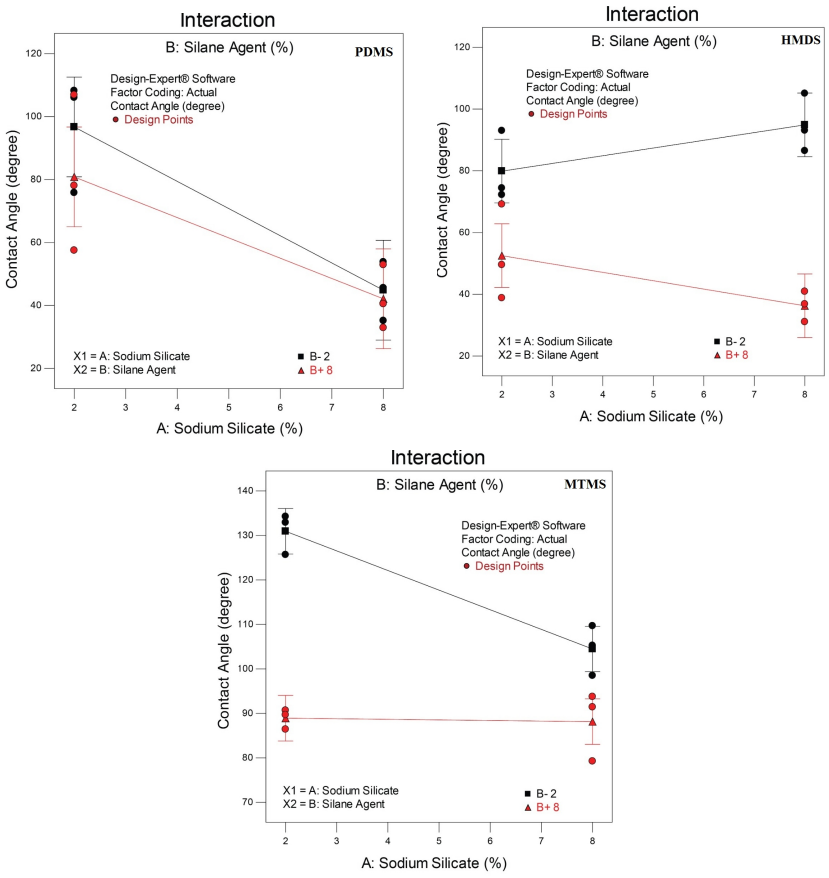

Figure 5 Model graph of interaction between sodium silicate and silane agent

Based on optimization using objective criteria in the form of contact angles at maximum levels, optimal use of sodium silicate and silane agents can be observed. The optimization results based on design expert software compared with those of uncoated glass are shown in Table 6 with range low level of 2 and high level of 8 for each variable.
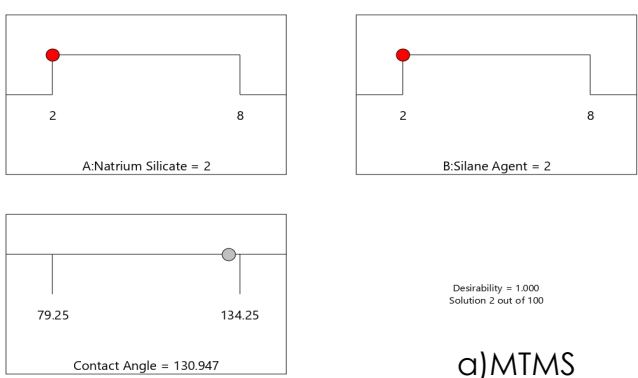

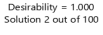

a)MTMS
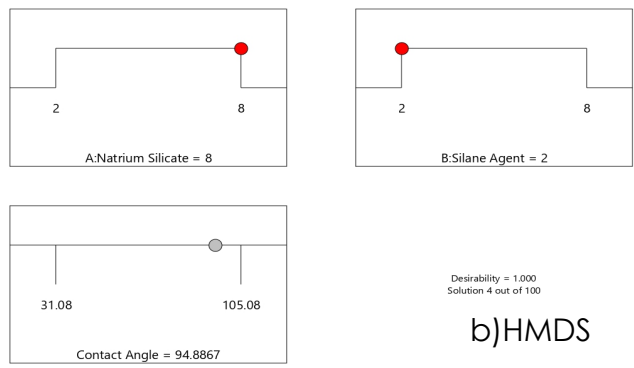

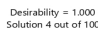

b)HMDS
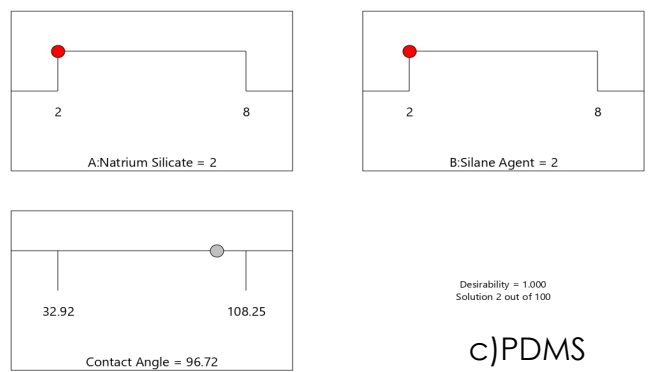

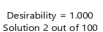

c)PDMS

Figure 6 Ramp result for the optimization

Moreover, confirmation of this optimization have been confirmed the analysis of 3 (six) samples with duplicate contact angle analysis. The optimization data from design expert software can be seen from ramps graphs in Figure 6.

Table 6 Optimization results of silica glass coating film and contact angle result of uncoated glass

\begin{tabular}{llllll}
\hline $\begin{array}{l}\text { Silane } \\
\text { Agent } \\
\text { Type }\end{array}$ & $\begin{array}{l}\text { Sodium } \\
\text { silicate } \\
(\%)\end{array}$ & $\begin{array}{l}\text { Silane } \\
\text { Agent } \\
(\%)\end{array}$ & $\begin{array}{l}\text { Contact } \\
\text { Angle } \\
\text { from DE } \\
\text { statistic } \\
\text { al } \\
\left({ }^{\circ}\right)\end{array}$ & $\begin{array}{l}\text { Desir } \\
\text { ability }\end{array}$ & $\begin{array}{l}\text { Contact } \\
\text { Angle } \\
\text { measurements } \\
\left({ }^{\circ}\right)\end{array}$ \\
\hline MTMS & 2.000 & 2.000 & 130.94 & $94.0 \%$ & 130.94 \\
HMDS & 8.000 & 2.000 & 94.89 & $86.2 \%$ & 94.89 \\
PDMS & 2.000 & 2.000 & 96.72 & $84.7 \%$ & 96.72 \\
Unco- & - & - & 18.6 & - & \\
ated & & & & & \\
\hline
\end{tabular}


Table 6 shows that the silica glass coating film, which uses $2 \%$ sodium silicate and $2 \%$ silane agent of MTMS, produces the highest contact angle at $130^{\circ}$ with desirability of 0.94 . However, coatings using surfacemodified silica can provide glass with hydrophobic properties (contact angle $>90^{\circ}$ ) compared with uncoated glass substrates. Glass plates without any coating, only have a contact angle of $18.58^{\circ}$, which indicates as hydrophilic.

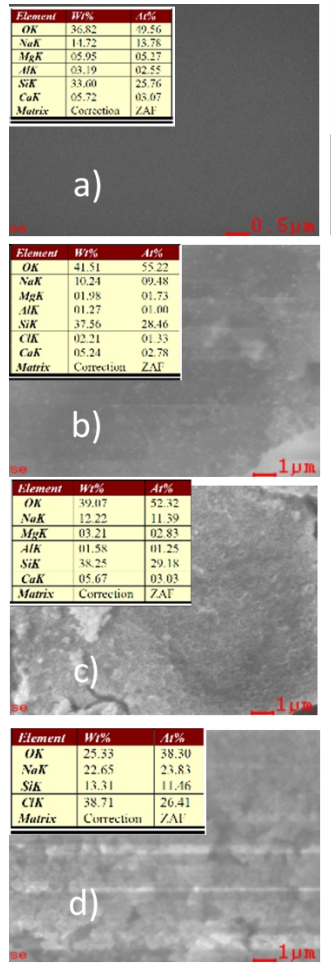

Figure 7 SEM-EDX mapping of (a) uncoated glass, (b) coated glass with modified silica-HMDS, (c) MTMS, and (d) PDMS

In addition, Figure 7 visualizes morphology and elemental analysis as basic surface analysis based on SEM-EDX mapping for samples among uncoated and coated glasses (samples with sodium silicate of $8 \%$ and silane agents of $8 \%$ ) regardless the optimum variables in Table 6. The SEM-EDX mapping was used to distinguish the effect of three silane agents. Silica content of uncoated glass (33.6\%) remained less than that of coated glass with several modifying agents. Through the same procedure, the highest increase of silica content can be achieved when silica coating is modified with MTMS (37.88\%). Meanwhile, the roughness of coated glass with HMDS resulted in a smoother surface and contact angle less than MTMS due to reduced roughness. Moreover, the hydrophobicity can be affected by modification agent ratios in releasing a contact angle [38].

\subsection{The Surface Roughness Analysis}

Table 7 summarizes the height surface of coated glass regard with height of surface $(\mathrm{nm})$ and root average (Ra, $\mathrm{nm}$ ). The height of surface silica from modified silica coating by MTMS, PDMS, and HMDS released the height surface approximately 48-76, 2573, and 9-20 nm, respectively. Moreover, the Ra of coated by MTMS, PDMS, and HMDS about 29-57, $16-$ 19, and 5-13 $\mathrm{nm}$, respectively. It confirmed the contact angle report (Table 6) that the silane agent of MTMS generated higher contact angle higher the height of surface and the Ra. The silane agent of MTMS on glass coating given a constructive effect on the surface roughness [38].

Table 7 The roughness parameter of coated glass of the silane agent by the AFM analysis

\begin{tabular}{|c|c|c|}
\hline Sample & $\begin{array}{l}\text { The height of } \\
\text { surface }(\mathrm{nm})\end{array}$ & $\mathrm{Ra}(\mathrm{nm})$ \\
\hline MTMS & $48-76$ & $29-57$ \\
\hline HMDS & $9-20$ & $5-13$ \\
\hline PDMS & $25-73$ & $16-19$ \\
\hline
\end{tabular}

Coated glass using silane agent of MTMS resulted rougher surface, and higher contact angle (more hydrophobic). It was confirmed by the contact angle measurement and the AFM analysis result in Table 6 and Figure 8.

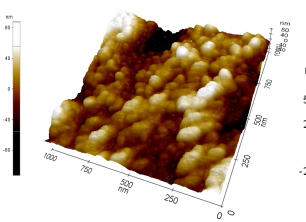

a)
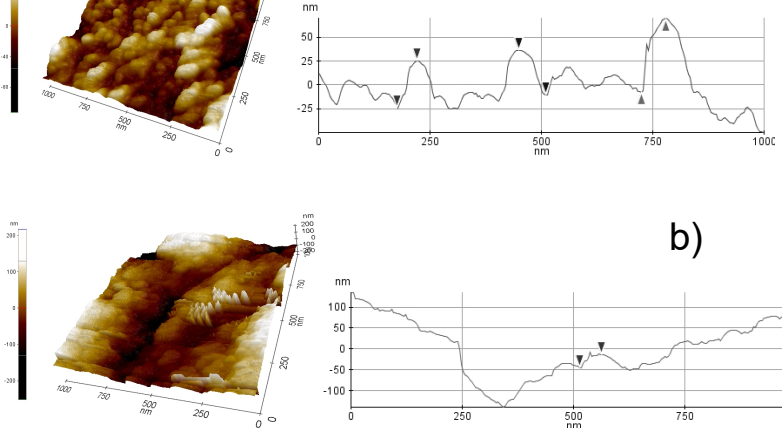

b)
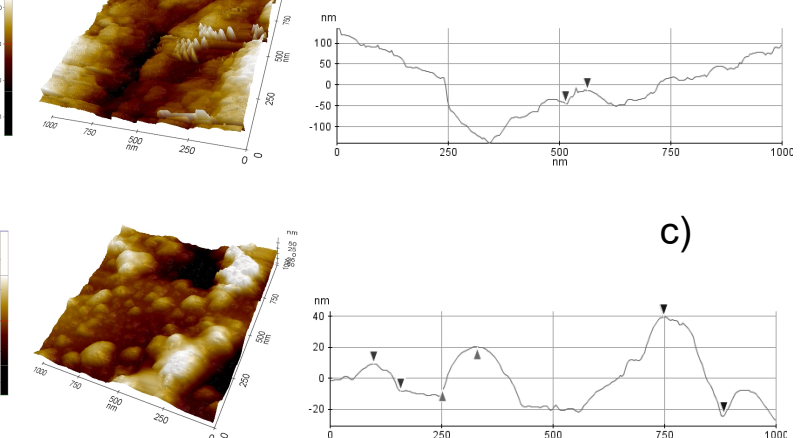

C)

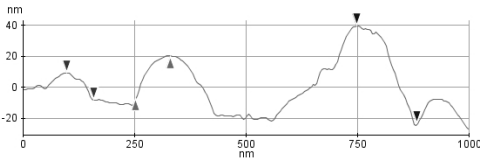

Figure 8 AFM of the surface roughness with silane agent of a)MTMS; b)HMDS; and c)PDMS

\subsection{CONCLUSION}

Considering the results of this study, we can conclude that the manufacture of silica glass coating films from geothermal waste using the sol-gel method obtained the best results with the silica sol-to- $\mathrm{HCl}$ ratio at $1 / 8$ $(v / v)$. The conditions obtained a surface area of $165.44 \mathrm{~m}^{2} / \mathrm{g}$, which was higher than that obtained with other ratios. Based on contact angle 
measurements, the glass coating using a modified thin layer of silica produced a hydrophobic glass surface with a contact angle of $>90^{\circ}$. However, after optimization, the highest contact angle achieved was $130.9^{\circ}$ with desirability of $94.0 \%$ obtained by using of $2 \%$ sodium silicate concentration and $2 \%$ MTMS.

\section{Acknowledgement}

The authors are grateful the Advanced Materials Laboratory and Diponegoro University who have contributed throughout the course of this research. This work was funded by the Institute for Research and Community Services Institute, Diponegoro University, under Grant No. 385-98/UN7.P4.3/PP/2019.

\section{References}

[1] Ganesh, V. A., Raut, H. K., Nair, A. S., and Ramakrishna, S. 2011. A Review on Self-cleaning Coatings. Journal of Materials Chemistry. 21 (41): 16304-16322.

DOI: $10.1039 / \mathrm{cljm} 12523 \mathrm{k}$.

[2] Barroso, G., Li, Q., Bordia, R. K., and Motz, G. 2019. Polymeric and Ceramic Silicon-based Coatings - A Review. Journal of Materials Chemistry A. 7(5): 1936-1963. DOI: $10.1039 /$ c8ta09054h.

[3] Alam, K., Ali, S., Saboor, A., Salman, M., Maoz, Humayun, M., Sadiq, M., and Arif, M. 2019. Antireflection, Superhydrophilic Nano-Porous $\mathrm{SiO}_{2}$ Coating based on Aerosol Impact Spray Deposition Technique for Solar PV Module. Coatings. 9(8): 1-13. DOI: $10.3390 /$ coatings 9080497 .

[4] He, S., Wang, Z., Hu, J., Zhu, J., Liping, W., and Chen, Z. 2018. Formation of Superhydrophobic Micronanostructured Iron Oxide for Corrosion Protection of N80 Steel. Materials \& Design. 160: 84-94.

DOI: 10.1016/j.matdes.2018.09.002.

[5] Darband, G. B., Aliofkhazraei, M., Khorsand, S., Sokhanvar, S., and Kaboli, A. 2020. Science and Engineering of Superhydrophobic Surfaces: Review of Corrosion Resistance, Chemical and Mechanical Stability. Arabian Journal of Chemistry. 13(1): 1763-1802.

DOI: 10.1016/j.arabjc.2018.01.013.

[6] Bravo, J., Zhai, L., Wu, Z., Cohen, R. E., and Rubner, M. F. 2007. Transparent Superhydrophobic Films Based on Silica Nanoparticles. Langmuir. 23(13): 7293-7298. DOI: 10.1021/la070159q.

[7] Zu, X., Zhang, Z., Ren, G., Men, X., Ge, B., and Zhou, X. 2014. Designing Transparent Superamphiphobic Coatings Directed by Carbon Nanotubes. Journal of Colloid and Interface Science. 421: 141-145.

DOI: 10.1016/j.jcis.2014.01.026.

[8] Adam, F., Appaturi, J. N., and lqbal, A. 2012. The Utilization of Rice Husk Silica as a Catalyst: Review and Recent Progress. Catalysis Today. 190(1): 2-14. DOI: 10.1016/j.cattod.2012.04.056.

[9] Kow, K. W., Yusoff, R., Aziz, A. R. A., and Abdullah, E. C. 2014. From Bamboo Leaf to Aerogel: Preparation of Water Glass as a Precursor. Journal of Non-Crystalline Solids. 386: 76-84.

DOI: 10.1016/j.jnoncrysol.2013.11.041.

[10] Silviana, S., and Bayu, W. J. 2018. Silicon Conversion from Bamboo Leaf Silica by Magnesiothermic Reduction for Development of Li-ion Baterry Anode. MATEC Web of Conference. 156: 1-4.

DOI: $10.1051 /$ matecconf/201815605021.
[11] Affandi, S., Setyawan, H., Winardi, S., Purwanto, A., and Balgis, R. 2009. A Facile Method for Production of HighPurity Silica Xerogels from Bagasse Ash. Advanced Powder Technology. 20(5): 468-472. DOI: 10.1016/j.apt.2009.03.008

[12] Norsuraya, S., Fazlena, H., and Norhasyimi, R. 2016. Sugarcane Bagasse as a Renewable Source of Silica to Synthesize Santa Barbara Amorphous-15 (SBA-15). Procedia Engineering. 148: 839-846. DOI: 10.1016/j.proeng.2016.06.627.

[13] Harun, Z., Shohur, M. F., Jamalludin, M. R., Yunos, M. Z. and Basri, H., 2014. Hydrophilicity Effect of Rice Husk Silica on Mixed Matrix PSF Membrane Properties. Jurnal Teknologi. 70(2). DOI: $10.11113 /$ jt.v70.3428.

[14] Marto, A. and Tan, C.S., 2016. Properties of Coal Bottom Ash from Power Plants in Malaysia and Its Suitability as Geotechnical Engineering Material. Jurnal Teknologi. 78/85). DOI: $10.11113 /$ jt.v78.9603.

[15] Setiawan, F. A., Rahayuningsih, E., Petrus, H. T. B. M., Nurpratama, M. I., and Perdana, I. 2019. Kinetics of Silica Precipitation in Geothermal Brine with Seeds Addition: Minimizing Silica Scaling in a Cold Re-injection System. Geothermal Energy. 7(22): 1-16. DOI: 10.1186/s40517-019-0138-3

[16] Silviana, S., Hasbi, R. M., Sagita, C. P., Nurhayati, O. D., Fauzan, A., Suhartana, and Hatmoko, J. U. D. 2017. Natural Silica of Solid Waste from Geothermal Drilling in Dieng as Silica Gel through Environmentally Benign Processing (in Indonesian). Seminar Nasional Teknologi Hijau. 2: 341-346.

[17] Silviana, S., Sanyoto, G.T., Darmawan, A., and Sutanto, H. 2020. Geothermal Silica Waste as Sustainable Amorphous Silica Source for The Synthesis of Silica Xerogels. Rasayan J. Chem. 13(3): 1692-1700(2020). http://dx.doi.org/10.31788/RJC.2020.1335701.

[18] Silviana, S., Rambe, I. N. H., Sudrajat, H., and Zidan, M. A. 2019. Statistical Approaching of Sol-gel Process in Preparation of Silica Aerogel Derived from Geothermal Silica by Several Acids. AIP Conference Proceedings 2202. 020069. https://doi.org/10.1063/1.5141682.

[19] Silviana, S., Darmawan, A., Subagio, A., and Dalanta, F. 2019. Statistical Approaching for Superhydrophobic Coating Preparation using Silica Derived from Geothermal Solid Waste. ASEAN Journal of Chemical Engineering. 19(2): 91-99.

https://doi.org/10.22146/ajche.51178.

[20] Silviana, S., Darmawan, A., Dalanta, F., Subagio, A., Hermawan, F., Milen Santoso, H. 2021. Superhydrophobic Coating Derived from Geothermal Silica to Enhance Material Durability of Bamboo Using Hexadimethylsilazane (HMDS) and Trimethylchlorosilane (TMCS). Materials 2021. 14(3): 530. https://doi.org/10.3390/mal 4030530.

[21] Jalali, S. R. S., Sobat, S., and Farzi, G. 2018. Surface Modification of Silica Nanoparticle Using Dichlorodimethylsilane for Preparation of Self-cleaning Coating Based on Polyurethane and Polydimethylsiloxane. Materials Research Express. 5(9): 1-15. DOI: 10.1088/2053-1591/aad607.

[22] Mahadik, S. A., Mahadik, D. B., Kavale, M. S., Parale, V. G., Wagh, P. B., Barshilia, H. C., Gupta, S. C., Hegde, N. D., and Rao, A. V. 2012. Thermally Stable and Transparent Superhydrophobic Sol-gel Coatings by Spray Method. Journal of Sol-Gel Science and Technology. 63: 580-586. DOI: 10.1007/s10971-012-2798-3.

[23] Shao, Z., Luo, F., Cheng, X., and Zhang, Y. 2013. Superhydrophobic Sodium Silicate Based Silica Aerogel Prepared by Ambient Pressure Drying. Materials Chemistry and Physics. 141(1): 570-575.

DOI: 10.1016/j.matchemphys.2013.05.064. 
[24] Zhang, Y., Dong, B., Wang, S., Zhao, L., Wan, L., and Wang 2017. Mechanically Robust, Thermally Stable, Highly Transparent Superhydrophobic Coating with Lowtemperature Sol-gel Process. RSC Advances. 7(75): 4735747365. DOI: 10.1039/c7ra08578h.

[25] Wang, S. D., and Luo, S. S. 2012. Fabrication of Transparent Superhydrophobic Silica-based Film on a Glass Substrate. Applied Surface Science. 258(14): 5443-5450. DOI: 10.1016/j.apsusc.2012.02.032

[26] Naderizadeh, S., Athanassiou, A., and Bayer, I. S. 2018. Interfacing Superhydrophobic Silica Nanoparticle Films with Graphene and Thermoplastic Polyurethane for Wear/Abrasion Resistance. Journal of Colloid and Interface Science. 519: 285-295. DOI: 10.1016/j.jcis.2018.02.065.

[27] Darmawan, A., Utari, R., Saputra, R. E., Suhartana, and Astuti, Y. 2018. Synthesis and Characterization of Hydrophobic Silica Thin Layer Derived from Methyltrimethoxysilane (MTMS). IOP Conference Series: Material Science and Engineering. 299: 1-16. DOI: $10.1088 / 1757-899 X / 299 / 1 / 012041$

[28] Cai, Y., Li, J., Yi, L, Yan, X., and Li, J. 2018. Fabricating Superhydrophobic and Oleophobic Surface with Silica Nanoparticles Modified by Silanes and EnvironmentFriendly Fluorinated Chemicals. Applied Surface Science. 450: 102-111. DOI: 10.1016/j.apsusc.2018.04.186.

[29] Chang, H., Tu, K., Wang, X., and Liu, J. 2015. Fabrication of Mechanically Durable Superhydrophobic Wood Surfaces Using Polydimethylsiloxane and Silica Nanoparticles. RSC Advances. 5(39): 30647-30653. DOI: 10.1039/c5ra03070f.

[30] Boussaa, S. A., Kheloufi, A., Zaourar, N. B., and Bouachma, S. 2017. Iron and Aluminium Removal from Algerian Silica Sand by Acid Leaching. Acta Physica Polonica A. 132: 1082-1086.

DOI: 10.12693/APhysPolA.132.1082.

[31] Seidel, A., and Zimmels, Y. 1998. Mechanism and Kinetics of Aluminum and Iron Leaching from Coal Fly Ash by Sulfuric Acid. Chemical Engineering Science. 53(22): 38353852.
DOI: $10.1016 /$ S0009-2509(98)00201-2.

[32] Setyawan, H., Samsiadi, V., and Ambarwati. 2010. Hydrophobic Glass Coated with Surface Modified-silica Film Prepared from Sodium Silicate. Proceeding lst International Seminar on Fundamentals and Application of Chemical Engineering ISFAChE Bali-Indonesia E003.

[33] Lee, S. E., Ahn, Y., Lee, J. S., Cho, C. H., Hong, C. K., and Kwon, O. H. 2017. Ambient-pressure Drying Synthesis of High-performance Silica Aerogel Powders by Controlling Hydrolysis Reaction of Water Glass. Journal of Ceramic Process Research. 18(11): 777-782.

[34] Sidik, S. M., Jalil, A. A., Triwahyono, S. and Asli, U. A. 2016. $\mathrm{CO}_{2}$ Reforming of Methane Over $\mathrm{Ni}$ Supported on Mesostructured Silica Nanoparticles (Ni/Msn): Effect of $\mathrm{Ni}$ Loading. Jurnal Teknologi. 78(8-3). DOI: 10.11113 /jt.v78.9560.

[35] Esposito, S. 2019. "Traditional" Sol-Gel Chemistry as a Powerful Tool for the Preparation of Supported Metal and Metal Oxide Catalysts. Materials. 12(4): 1-25. DOI: $10.3390 / \mathrm{mal} 2040668$

[36] Cui, H., Zayat, M., and Levy, D. 2006. Effect of $\mathrm{HCl}$ on the PPO Assisted Sol-gel Synthesis of Olivine-type $\mathrm{CO}_{2} \mathrm{SiO}_{4}$ Ultrafine Particles. Journal of Sol-Gel Science Technology. 40: 83-87. DOI: 10.1007/s10971-006-8216-y

[37] Wu, S.-H., Mou, C. Y., and Lin, H. P. 2013. Synthesis of Mesoporous Silica Nanoparticles. Chemical Society Reviews. 42(9): 3862-3875. DOI: 10.1039/c3cs35405a

[38] Pilipavičius, J., Kazadojev, I., Beganskienè, A., and Melninkaitis, A. 2008. Hydrophobic Antireflective Silica Coatings via Sol-gel Process. Materials ScienceMedziagotyra. 14(4): 283-287.

[39] Widati, A. A., Nuryono, N., Kartini, I. 2019. Water-repellent Glass Coated with $\mathrm{SiO} 2-\mathrm{TiO} 2-m e t h y l t r i m e t h o x y s i l a n e$ through Sol-gel Coating. AIMS Materials Science. 6(1): 10 24.

DOI: 10.3934/matersci.2019.1.10. 